\title{
An Investigation of pH Effects on the Properties of the Fabricated Banana Flower Extracts-based Organic Solar Cell
}

\author{
SUTIKNO, IAN YULIANTI and DANY SIGIT SAPUTRA \\ Physics Department, Faculty of Mathematics and Natural Sciences, \\ Universitas Negeri Semarang (Unnes), D7 Building, $2^{\text {nd }}$ Floor, Sekaran Campus, \\ Gunungpati, Semarang, Republic of Indonesia, 50229. \\ *Corresponding author E-mail: sutiknomadnasri@ mail.unnes.ac.id \\ http://dx.doi.org/10.13005/ojc/330137
}

(Received: January 10, 2017; Accepted: February 08, 2017)

\begin{abstract}
The purpose of this research is to fabricate banana flower extracts-based dye-sensitized solar cell (DSSC) using spin coating method. DSSC is made of photoactive material of banana extract by spincoating method and thermal evaporation, using indium tin oxide (ITO) substrate. Spincoater speed, coating duration and heating temperature are fixed as controlled variables, anthocyanin $\mathrm{pH}$ is fixed as independent variable, while optical and electrical properties of solar cell device are fixed as dependent variables. The anthocyanin content decreased as well as the $\mathrm{pH}$ increased and the voltage knee also increased. The $\mathrm{pH}$ enhance has caused the current generation of device decreased.
\end{abstract}

Keywords: DSSC; Organic photovoltaics; Photovoltaics; Synthesis method.

\section{INTRODUCTION}

Dye-sensitized solar cell (DSSC) is the third generation solar cell which is considered as future alternative energy source, a dye-sensitized photovoltaic cell of $\mathrm{TiO}_{2}$. The basic principle of DSSC is transforming light energy into electrical energy. When a dye molecule absorbs light, an electron is replaced with an excited state, and this can jump to conduction band of $\mathrm{TiO}_{2}$. Equal to this process, the photoelectric effect is obtained by dye pigments ${ }^{1}$. The production cost of silicon based-conventional solar cell is relatively high and it consumes more energy. This device has been attracting many researchers at last decade since the first report made by Gratzel dan coworkers ${ }^{2}$ due to DCCS is produced at relatively low $\operatorname{cost}^{1,3}$, easy prepared and fabricated, simple design structure $^{4}$, light, potentially applicable in flexible devices as if compared with conventional pn junction devices $^{5}$, transparent module construction, better performance on wider tap, lower sensitivity to the angle of incidence and condition of darkness ${ }^{6}$, and has a high conversion efficiency ${ }^{7}$. Silicon basedconventional solar cell has achieved efficiency as 
high as $20 \%$ while highest organic solar cell efficiency ever achieved is $1,49 \%^{8}$.

The selected material advantages include ${ }^{1,7}$ : available in nature in large quantities ${ }^{1,4}$, easy to use, non-toxic, ecofriendly and easily biodegradable. The types of materials that will be developed ${ }^{2}$ include flowers, plant leaves, fruits, fruit peels and roots. The photoactive materials extracted from various types of flowers such as red cabbage, blue bean ${ }^{2}$, raspberry (Rubus Ideaus), black carrot (Daucuscarota L.), rosella (Hibiscus Sabdariffa L.) ${ }^{9}$, red bougenville flower ${ }^{1}$, black tea, banana flower ${ }^{10,11}$, Allium Cepa L. ${ }^{11}$, beans or promegranate skin ${ }^{5}$, flowers canaries and radishes. The leaves of plants that can be extracted the photoactive ingredient include: basella alba rubra or malabar spinach or typhoon spinach ${ }^{7}$, and mapple leaf. Fruits ever extracted by some researchers to compose DSSC include: prickly pir, beets ${ }^{5}$, achoite seed, mulberry, strawberry and blackberry. Anthocyanin also can be extracted of grap skins ${ }^{11}$ and bieten roots ${ }^{12}$, Beta vulgaris ${ }^{4}$, red potatoes, pomea pescaprae, and Imperata cylindrica (L.) Beauv and Paspalum conjugatum Berg ${ }^{1}$. The anthocyanin quantity in the sample decreased as well as it's $\mathrm{pH}$ increased from 3 up to $7^{11}$. The pigment is present on the different parts of plants which including flower petals, fruits, leaves, stems, and roots ${ }^{13}$. The acid treatment has caused pigment spectrum absorption spreading and cell efficiency increasing. The acid treatment can increase efficiency of pigment cell $I$. Pescaprae from $0,45 \%$ up to $0,53 \%$. How does the effect $\mathrm{pH}$ level of banana anthocyanin extract on the electrical property of the fabricated DSSC device?

\section{MATERALS AND METHOD}

The materials used in this research comprise indium titanium oxide (ITO) substrate $1800 \AA$ and sheet resistance $7 \mathrm{~W} / \mathrm{sq}$, banana flower

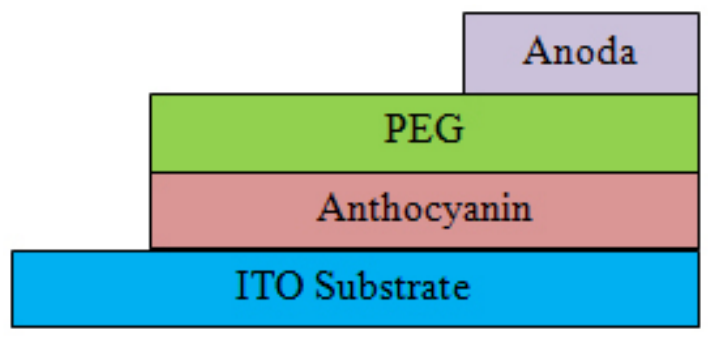

Fig. 1: Structure of DSSC extract anthocyanin, aluminium foil, copper $(\mathrm{Cu})$ foil, nitrate ammonium, DI-water, (PEG), ammonia, ethanol, and acetyl acetone. The production equipments consist of spincoater with maximum speed $10.000 \mathrm{rpm}$, oxidation/vacuum furnace, evaporator, sputtering reactor, ultrasonic cleaning bath, and IV-meter. Additionally, the characterization equipments utilized include FTIR, Ocean Optic VisNir USB4000 spectrophotometer, I-V meter (Four point probe meter) and UV-vis spectrometer.

The organic solar cell structure if seen from the side view is designed as Figure 1. First, the ITO substrate was cleaned using ultrasonic cleaning bath in the acetone isoprophyl alcohol, and then dried using dry nitrogen. A conductive layer of banana flower extract anthocyanin with thickness of $40 \mathrm{~mm}$ was coated on the substrate using spincoater. At this step, some parameters were controlled to optimize the conductive layer thickness. The thickness, optical property and microstructure were also optimized. The aluminium electrode in thickness of $120 \mathrm{~nm}$ was formed through thermal evaporation at vacuum condition $1,33 \times 10^{-4} \mathrm{~Pa}$.

The cell active electrode area equals to 6 $\mathrm{mm}^{2}$. The relatioship between voltage and current is measured (Four point probe meter) at two conditions namely dark and illuminated with incident light for wavelength of $500 \mathrm{~nm}$ and intensity of $16,7 \mathrm{~mW} / \mathrm{cm}^{2}$. This solar cell was illuminated on the ITO side using Xe lamp of $50 \mathrm{~W}$.

In this research, when thin films of PEG and banana flower extract were coated, the generated electrical current either on the dark or light condition was fixed as dependent variable, while spincoater speed was fixed as independent variable and the room temperature was controlled at $25^{\circ} \mathrm{C}$. The electrical conductiviy was measured using four-point

Table 1: Weight fractions made for preparation of banana flower extraction

\begin{tabular}{cccc}
\hline & $\begin{array}{c}\text { Weight } \\
\text { fraction (X) }\end{array}$ & $\begin{array}{c}\text { Banana } \\
\text { flower (gram) }\end{array}$ & $\begin{array}{c}\text { Solution } \\
\text { (gram) }\end{array}$ \\
\hline A & 0,1 & 21 & 186 \\
B & 0,2 & 47 & 186 \\
C & 0,3 & 80 & 186 \\
D & 0,4 & 124 & 186 \\
\hline
\end{tabular}


probe meter. Aluminium contact pad was metallized at the controlled temperature and thermal pressure namely $961,93^{\circ} \mathrm{C}$ and $1,33 \times 10^{-4} \mathrm{~Pa}$. The spincoater speed was controlled at $500 \mathrm{rpm}$ and rotated during 30 seconds.

The relationship between $\mathrm{pH}$ of banana flower extract with range of absorption wavelength, electrical conductivity and microstructure were accurately investigated and analyzed. The photoactive layer is also analyzed spesifically. The solar cell performance is determined by analyzing the relationship between current and voltage behavior.

\section{RESULTS AND DISCUSSION}

The fresh banana flower was sliced, blended and extracted into anthocyanin extract through some steps. The extraction result was filtered and heated while stirring at speed of $500 \mathrm{rpm}$. The

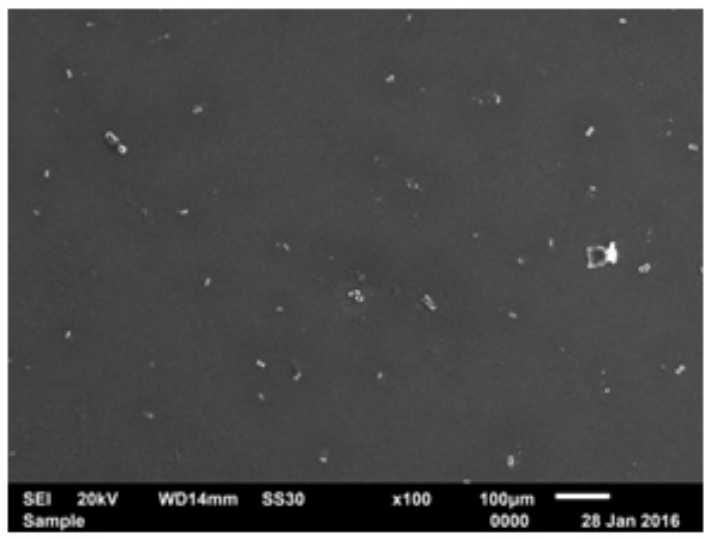

(a)

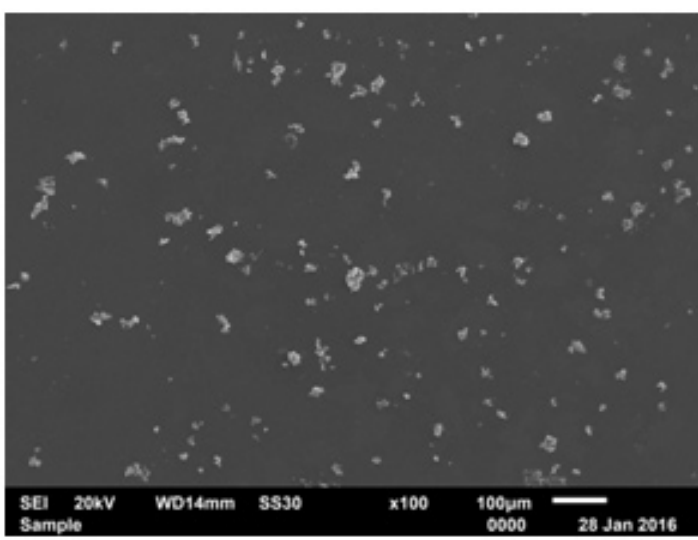

(c) solution was prepared by mixing $30 \mathrm{~g}$ aquadest, 150 $\mathrm{g}$ ethanol, and $6 \mathrm{~g}$ acid acetate during 30 seconds to achieve homogeneous. Then amount of $20 \mathrm{~g}$ pieces of banana flower and solution were put in the blender to be crushed. The extracted banana were prepared in weight fractions of $0,1,0,2,0,3$ and 0,4 . The formula used to compute the weight fraction is as the following:

$x=\frac{a}{b}$

where $X=$ weght fraction, $a=$ mass of banana flower and $b=$ mass of solvent. The extraction fraction is listed as Table 1.

The solution used for distillation process consists of aquadest $(30 \mathrm{~g})$, ethanol $96 \%(150 \mathrm{~g})$ and acid acetate $(6 \mathrm{~g})$. For sample $A$, ethanol was separated of solution by distillation process for 2

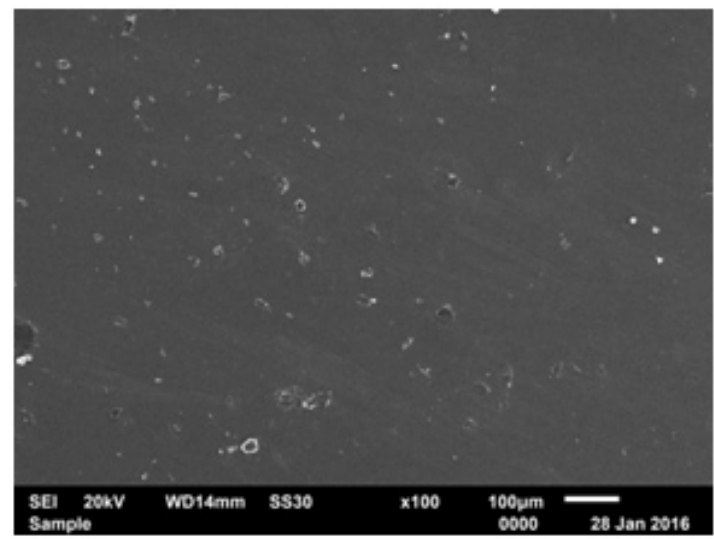

(b)

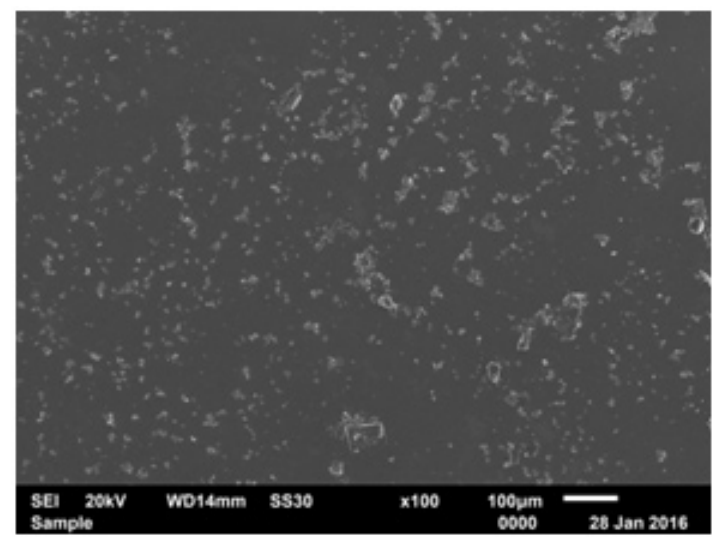

(d)

Fig. 2: Microstuctures of thin films of banana flower extract for pH levels: (a) 2, (b) 3, (c) 4, and 5 
hours at temperature $95^{\circ} \mathrm{C}$ and it started to drip in the tenth minute. Sample of weight fraction 0,2 was distilled at temperatures $75-90^{\circ} \mathrm{C}$ for 145 minutes and vaporization speed $0,86 \mathrm{ml} /$ minute, while the sample of weight fraction of 0,2 was distilled at the same temperature for 150 minutes and vaporization speed $0,53 \mathrm{ml} /$ minute. The solution volume before distillation process equalled to $107 \mathrm{ml}$ and after distillation it became $23 \mathrm{ml}$ and dark purple. Then this solution were prepared at variated $\mathrm{pH}$ levels namely $3,4,5$ and 6 and they were marked $A, B, C$, and D respectively.
Figure 2 is a SEM image with magnification of 100X of banana flower extract layer at different $\mathrm{pH}(2,3,4$ and 5). In Figure 2(a), the bright spots which are visible clumps of sparse and increasingly $\mathrm{pH}$ rises, these clots are more numerous and meetings.

On the Figure 3, it is exhibited the relationship between transmittance of banana flower extract layer to ultraviolet exposure for wavelengths of $300-1000 \mathrm{~nm}$ at variated $\mathrm{pH}$ levels. Based on this relation, it can be taken a relation that as the $\mathrm{pH}$ level

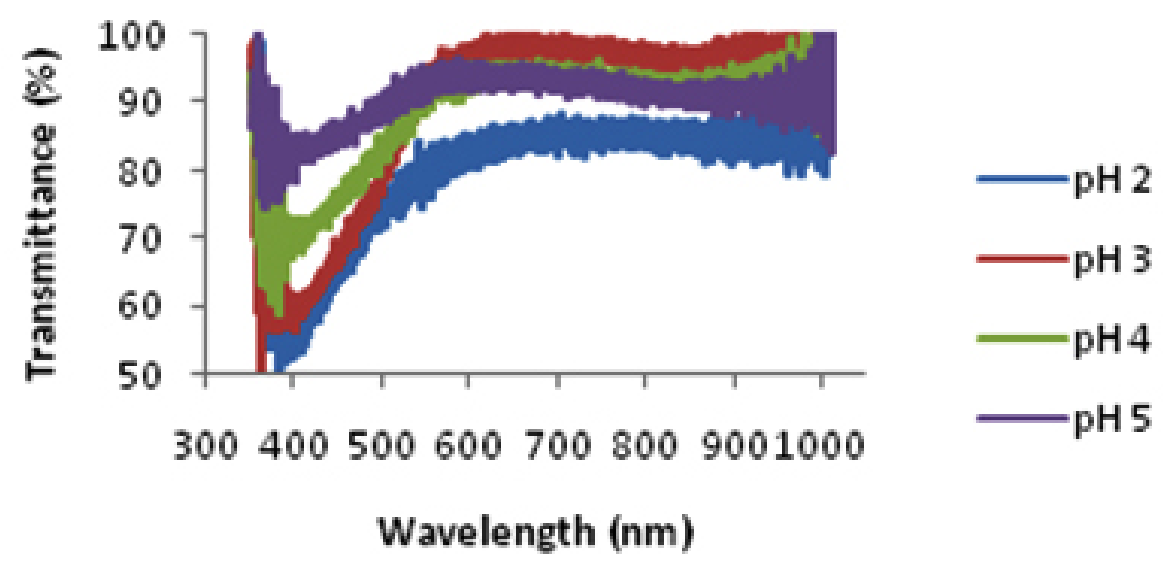

Fig. 3: Graph of light absorption with wavelengths of $300-400 \mathrm{~nm}$ for banana flower extract anthocyanin at different $\mathrm{pH}$

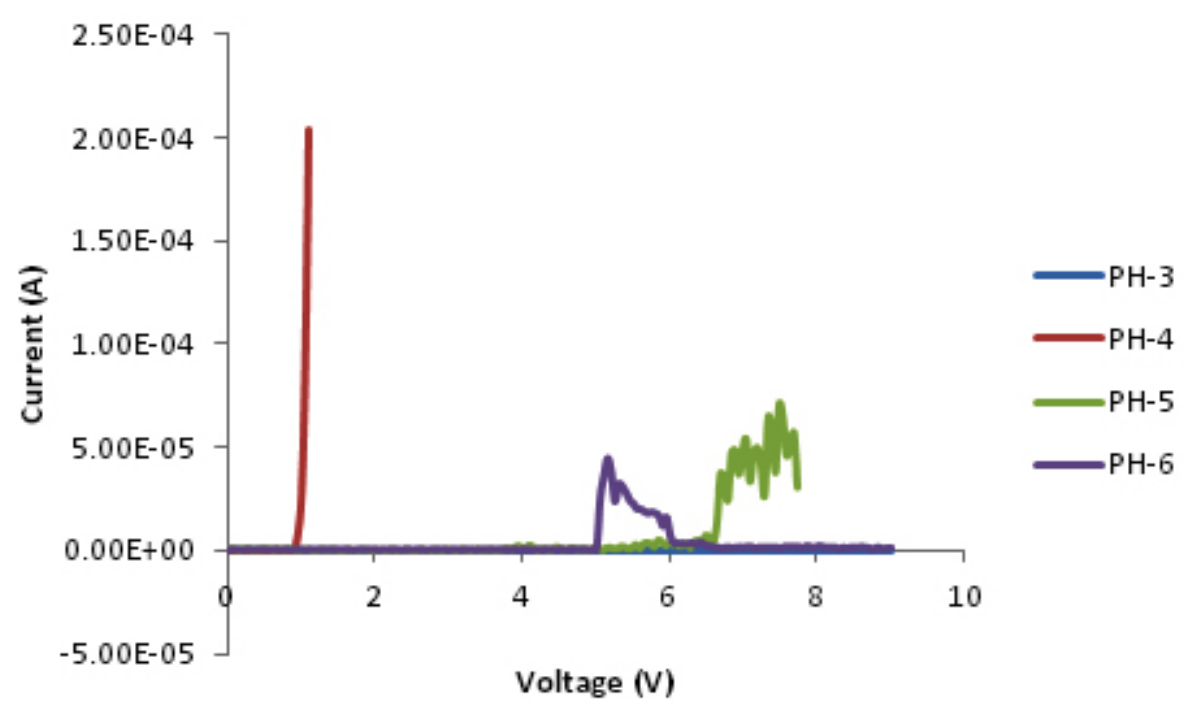

Fig. 4: I-V Curve of DSSC samples which are produced of first coating of photoactive material in the dark for different $\mathrm{pH}$ 


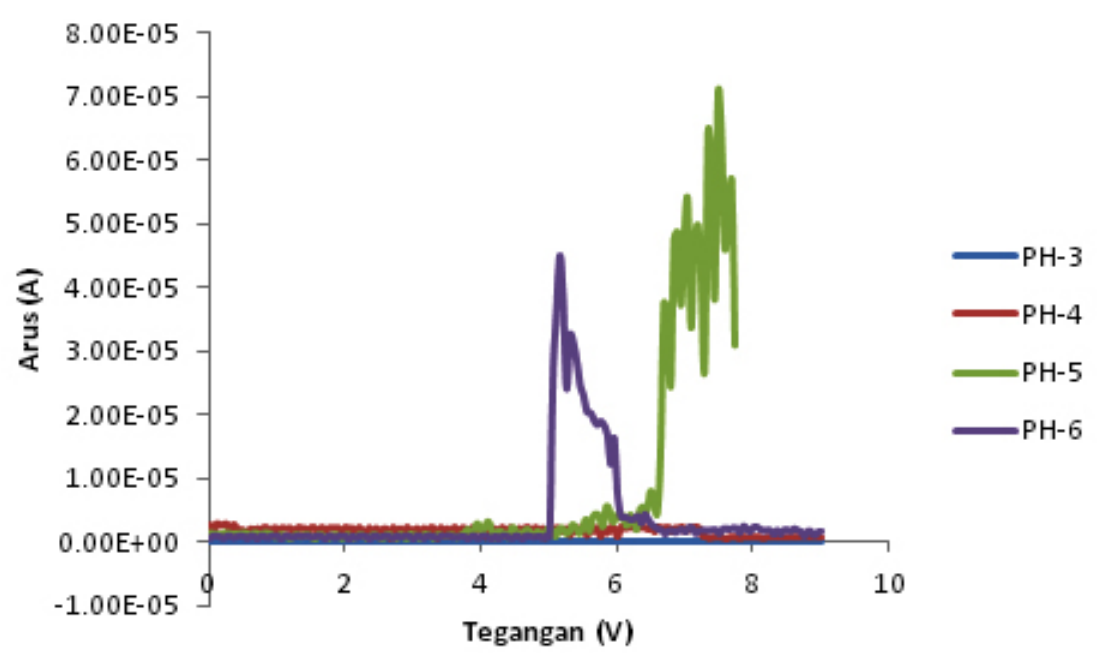

Fig. 5: I-V Curve of DSSC samples of second coating of photoactive material for different $\mathrm{pH}$ at dark condition

of solution increases the transmittance increseas as well, and at the $\mathrm{pH} 6$ will fall back.

To characterize thin films of banana flower extracts, the solution of banana flower extract is coated on the preparate glass in size of $1 \mathrm{~cm} \times 1,25$ $\mathrm{cm}$ using spincoater at speed of $500 \mathrm{rpm}$ for 30 seconds. This substrate size is adapted to electrical property characterization equipment which will be used. The substrates were immersed in the ethanol and shakened gently for 1 hour, cleaned using acetyle acetone, alcohol and aquadest and dried using spincoater to remove water. Then, the coated films were also dried on the oven at temperature $250^{\circ} \mathrm{C}$ for 10 minutes. The $\mathrm{pH}$ effect of solution on the film properties were investigated.

Four samples with each weight fraction of $A(0,1), B(0,2), C(0,3)$ and $D(0,4)$ were characterized using ocean optic Vis-Nir USB4000. This characterization aims to determine absorbances of banana flower extract for wavelengths of visible light up to infrared (350-100nm).

Next step is metallization process to make aluminium contact. Four DSSC samples (A, B, C and $\mathrm{D}$ ) of solution $\mathrm{pH}$ each is $3,4,5$ and 6 were metallized using evaporator which is installed by heating element (wolfram wires) to form aluminum pad. The electrical properties of fabricated DSSCs were characterized using IV-meter. The used organic materials can function well as a semiconductor material. Nearby at all pH levels, the Knee voltages were found. Additionally, at $\mathrm{pH} 3$, the knee voltage was not found (in the Fig. 4 it is indicated by blue line), at $\mathrm{pH} 4$, the Knee voltage was found about $1 \mathrm{~V}$ and shows the semiconductor typical. For $\mathrm{pH} 5$ and $\mathrm{pH}$ 6 the Knee Voltages were found in $5,5 \mathrm{~V}$ and $4,5 \mathrm{~V}$, respectively. There is a trend that the more the $\mathrm{pH}$ the more the Knee voltage.

At the low $\mathrm{pH}$ (4), the generated maximum current is relatively higher than that of high $\mathrm{pH}(\mathrm{pH} 5$ and 6). The voltage increase on the forward bias 0 up to 1 Volt has generated the electrical current sharply for DSSC sample of solution $\mathrm{pH} 3$ (it is indicated by red color line). The anthocyanin gist of sample decreased when $\mathrm{pH}$ incrased from $\mathrm{pH} 3$ to $\mathrm{pH} 7$ (Ekici et al., 2014). The generated electrical current at $\mathrm{pH} 5$ and $\mathrm{pH} 6$ were relatively slower than that of $\mathrm{pH} 3$ were caused the anthocyanin content at high $\mathrm{pH}$ decreased.

Figure 5 contains a DSSC curve with thicker photoactive material layer than the tested samples as indicated in Figure 4. In Figure 5, the Knee voltages of $\mathrm{pH} 4$ sample is not found, while for samples with $\mathrm{pH} 5$ and $\mathrm{pH} 6$ they were consistently found namely 
Knee voltages $6.5 \mathrm{~V}$ and $4.5 \mathrm{~V}$ respectively. The acid treatment leads to absorption spectrum of pigment widening and cell efficiency increasing.

\section{CONCLUSION}

The anthocyanin level in the solution of banana flower extract lessened as well as the $\mathrm{pH}$ of solution raised. The $\mathrm{pH}$ level increase of photoactive layer of DSSC sample has triggered the Knee voltage enhance and also the produced electrical current reduce. The acid treatment has created absorption pigment spectrum widening and cell efficieny augmenting.

\section{ACKNOWLEDGMENT}

We thank the Ministry of Research, Tehcnology, and Higher Education for funding this research through Competitive Grant Scheme under Contract No. 055/SP2H/LT/DRPM/2016. We also thank Mutaqin, S.Pd. (Technician of Physics Laboratory, Semarang State University) for his technical help and Dr. Fachrurrosyid (Researcher in the Physics Laboratory, Sebelas Maret University) for metallization service.

\section{REFERENCES}

1. Prima, E. C.; Yuliarto, B.; Suendo, V. Suyatman J. Mater. Sci. Mater. Electron. 2014, 25, 46034611

2. Gokilamani, N.; Muthukumarasamy, N.; Thambidurai, M.; Ranjitha, A.; Velauthapillai, D. J. Sol-Gel Sci. Technol. 2013, 66, 212219

3. Isah, K. U.; Ahmad, U.; Idris, A.; Kimpa, M. I.; Uno, U. E.; Ndamitso, M. M.; Alu, N. Mater. Renew. Sustain. Energy 2014, 3(39), 1-5

4. Tripathi, M.; Upadhyay, R.; Pandey, A.; Dubey, P. K. Ionics 2013, 19(8), 1179-1183

5. Gokilamani, N.; Muthukumaramy, N.; Thambidurai, M.; Rajintha, A.; Velauthapillai, D.; Senthil, T.S.; Balasundaraprabhu, R. J. Mater. Sci.: Mater. Electron. 2013, 24, 33943402

6. Szostak, R.; Souza, E.C.F.; Antunes, S.R.M.; Borges, C.P.F.; Andrade, A.V.C.; Rodrigues,
P.R.P.; Anyunes, A.C. J. Mater. Sci.: Mater. Electron. 2015, 26(4); 2257-2262

7. Gokilamani, N.; Muthukumarasamy, N.; Thambirudai, M.; Rajintha, A.; Velauthapillai, D. J. Sol-Gel Sci. Technol. 2014, 69; 17-20

8. Gokilamani, N.; Muthukumarasamy, N.; Thambidurai, M.; Rajintha, A.; Velauthapillai, D. Appl. Nanosci. 2015, 5, 297-303

9. Tekerek, S; Kudret, A; Alver, Ü. Indian J. Phys. 2011, 1, 1469 -1476

10. Sutikno, Dharmaputera; N.M.; Rahayu, S. J. Adv. Agric. Technol. 2014, 1(2), 89 -93

11. Ekici, L.; Simsek, Z.; Ozturk, I.; Sagdie, O.; Yetim, H. Food Anal. Methods 2014, 7, 13281336

12. Tripathi, M; Chawla, P. Ionics 2015, 21, 541546

13. Sutikno, Hakim, M.L.; Sugianto. Orient. J. Chem. 2016, 32(1), 165-170 